\title{
It's Baaaack: Zeroing, the US Department of Commerce, and US-Shrimp II (Viet Nam)
}

\author{
JAMES C. HARTIGAN * \\ Department of Economics, University of Oklahoma
}

\begin{abstract}
In its Final Modification for Reviews the US DOC announced on 14 February 2012 that it would cease the use of zeroing in the calculation of antidumping (AD) margins in all reviews as of 16 April 2012. However, it did not pertain to targeted dumping. In its Final Rule of 22 April 2014, it codified substantial discretion in calculating AD duties, including the use of zeroing, in targeted dumping. Thus the panel in US-Shrimp II (Viet Nam) erred in not finding 'as such' inconsistency by the US with the AD Agreement, despite this not being a targeted dumping complaint. Given the record of the US in complying with zeroing petitions, it should have incurred the burden of proof, which is not satisfied by these pronouncements. Market structure should be used by panels in 'as applied' inconsistency determinations. Viet Nam should have included an Article 3 violation in its complaint.
\end{abstract}

\section{Introduction}

As there have been several analyses of panel and Appellate Body $(\mathrm{AB})$ reports of simple and model zeroing ${ }^{1}$ in antidumping (AD) investigations (Bown and Sykes, 2008; Hoekman and Wauters, 2011; Prusa and Vermulst, 2011; Broude and Moore, 2013; Prusa and Roubini, 2013; Saggi and Wu, 2013; and Ahn and Messerlin, 2014), ${ }^{2}$ it would be tempting to dismiss another panel report on this topic as having nothing novel of legal and economic interest. ${ }^{3}$ However, there

\footnotetext{
*Email: hartigan@ou.edu.

Valuable comments were received from Chad Bown, Bill Davey, Jennifer Hillman, Rob Howse, Petros Mavroidis, Tom Prusa, and participants at the 2015 WTO Case Law Project Conference at EUI in Florence, Italy. They are not to be implicated.

1 Zeroing refers to the calculation of $\mathrm{AD}$ margins in which instances of an export price of a good exceeding the price of like product sold in the domestic market is not allowed to negate occurrences of the export price being exceeded by the price of like product in the domestic market. It is often termed the A-T or average to transaction method.

2 While not an analysis of a specific dispute, Bown and Prusa (2011) provide an informative assessment of the use of zeroing by the DOC in general.

3 This presumption would be due in no small part to Broude and Moore (2013) having provided an insightful analysis of the panel report for US - Anti-Dumping Measures on Certain Shrimp (Viet Nam), DS404.
} 
are three novel legal issues in US-Shrimp II (Viet Nam), ${ }^{4}$ for which a request for consultations was filed on 16 February 2012. The first and second issues are not significant in effect for the implementation of the panel's decisions in US-Shrimp II (Viet Nam). Rather, they are portentous for the future use of zeroing in AD investigations, particularly by the US Department of Commerce (DOC).

One pertains to the announcement by the DOC on 14 February 2012 of its Final Modification for Reviews in which it stated that it would cease the use of zeroing in the calculation of AD margins in administrative reviews, new shipper reviews, and expedited AD reviews as of 16 April 2012.5 Although the preliminary results for the sixth administrative review were issued on 7 March 2012,6 it is noteworthy that the DOC did not apply the Final Modification in this review, as the final report of the sixth administrative review was released after the date of application of the Final Modification (that is, the final report was released on 11 September 2012). ${ }^{7}$ Although the review was in process when the Final Modification became applicable, this would have been an opportunity for the DOC to dispel doubt that it was serious about reforming its policy.

The second is the Final Rule issued by the DOC on 22 April 2014. ${ }^{8}$ It addresses the matter of determination of $\mathrm{AD}$ margins in instances of targeted dumping. Essentially, it is a waiver of some provisions of the Final Modification. I will discuss the importance of the Final Rule and its nexus with the Final Modification below.

It is important to underscore that US-Shrimp II (Viet Nam) is not a targeted dumping dispute. Targeted dumping never was alleged by the DOC. The panel, however, stated that 'Viet Nam's arguments fail to appreciate the significance of the Final Modification for its assertion that the zeroing methodology is a measure of general and prospective application'. Thus the panel gave substantial weight to this document in its rejection of Viet Nam's 'as such' claim. My view is that the panel failed to appreciate the significance of the opening the DOC gave itself through the Final Modification for continued use of zeroing in instances where targeted dumping is alleged. The burden of proof that zeroing was discontinued by publication of the Final Modification should have resided with the US. Given the record of the US in responding to preceding determinations by panels regarding zeroing, my view is that the US failed to satisfy this burden. Subsequent publication of the Final Rule affirms the concern that the panel missed an opportunity to sustain the pressure on the DOC to discontinue this method of calculating AD margins. Thus one importance of US-Shrimp II (Viet

4 United States - Anti-Dumping Measures on Certain Shrimp from Viet Nam, DS429.

577 Federal Register 8101.

677 Federal Register 13547.

777 Federal Register 55800.

879 Federal Register 22371. 
Nam) is its implications for the plausible proliferation of targeted dumping allegations in $\mathrm{AD}$ investigations by the DOC.

Thus my view is that the panel erred in its determination that Viet Nam failed to establish that the DOC's simple zeroing method was 'as such' inconsistent with Article 9.3 of the Anti-Dumping Agreement (ADA) and Article VI:2 of the General Agreement on Tariffs and Trade (GATT) 1994. In reaching this determination, I consider the record of the US in being the respondent in prior zeroing disputes, the incrementalism of US compliance with previous zeroing verdicts in which it was found to be inconsistent with the ADA (Saggi and Wu, 2013), the text of the Final Modification, and the text of the Final Rule. In particular, I believe that the texts do not provide sufficient disciplines regarding use of zeroing in future $\mathrm{AD}$ investigations.

The third issue is the failure of the panel to invoke the opportunity to consider market structure in assessing the consistency of the actions by the US with regard to its obligations under Articles 6.10 and 9.2 of the ADA. This pertains to the presumption by the DOC that all 'producers/ exporters' in a non-market economy (NME) belong to a single entity, and the assignment of a single $\mathrm{AD}$ margin to each of these firms. I concur with the judgment of the panel of 'as such' inconsistency. However, the panel could have made its determination much more emphatic through invocation and analysis of the structure of the market for the production of frozen warmwater shrimp.

The preceding analyses of panel and $\mathrm{AB}$ reports regarding zeroing has not explored the context of market structure in assessing the reasonableness of the DOC's calculation of AD margins. The shrimp industry provides a valuable vehicle for doing so. It is about as close to the theoretical construct of perfect competition as one can get. I will contend that the NME entity rate's appropriateness 'as such' or 'as applied' can be inferred readily through the prism of market structure.

In my discussion of market structure in the context of the particulars of the warmwater shrimp industry, I contend that the greater production volatility of the wild-caught domestic production arguably is a more important source of the seasonably low domestic prices than the less volatile (farmed) imports. That the original investigation did not disentangle the relative importance of domestic and imported sources of injurious pricing could have been a basis for complaint by Viet Nam of an Article 3 violation of the ADA on the part of the US.

I will continue with a discussion of whether or not the petition by the US industry should have been filed under the ADA, while being mindful that it would not have been appropriate for the panel to entertain it. In particular, I will contend that the evidence in the petition and the recent evolution of the US shrimp industry are more supportive of filing under the Agreement on Safeguards (ASG). Given the magnitude of the AD margins computed for the NME entity by the DOC for an approximately perfectly competitive industry, I will consider whether or not a petition under the Agreement on Subsidies and Countervailing Measures (ASCVM) 
may have been more defensible. Ultimately, I will contend that the US government may have missed an opportunity to provide greater protection to its shrimp industry under the Sanitary and PhytoSanitary Agreement (SPS), as a matter of food safety could have been alleged.

\section{What did the panel address?}

The salient issues, in my view, that the panel addressed begin with the inconsistency (as such and as applied) with Art 9.3 of the ADA and Art VI: 2 of the GATT. This restricts the amount of the $\mathrm{AD}$ to being less than or equal to the dumping margin.

Secondly, Articles 6.10 and 9.2 of the ADA are considered. Article 6.10 concerns appropriate notification of interested parties, including the opportunity to respond under assurance of confidentiality. Article 9.2 stipulates the non-discriminatory collection of duties in appropriate amounts. A specific concern is the rebuttable proposition under US law in which all companies in an NME are presumed to belong to a single entity.

The panel also revisited the decision of the panel in US-Shrimp I (Viet Nam) regarding Article 6.8 and Annex II(1)of the ADA. This pertains to the use of facts available (FA) when an 'interested party' declines to provide 'necessary information within a reasonable period or significantly impedes the investigation'.

The panel also considered claims under Articles 9.4, 11.1, 11.2, 11.3, and 18.1 of the ADA. Additionally, claims under Articles 3.8 and 19.1 of the Dispute Settlement Understanding were addressed. Section 129 (c)(1) of the Uruguay Round Agreements Act of the US in 1994 also was considered. These either were discussed thoroughly by Broude and Moore, or I have nothing of interest to introduce.

\section{A few pertinent facts}

The original investigation named Brazil, China, Ecuador, India, Thailand, and Vietnam as producers of subject merchandise, and commenced on 31 December 2003. The final report of the US International Trade Commission (USITC) was issued in January of $2005 .^{9}$ The USITC determined that approximately $95 \%$ of US production was wild-caught and the remainder was farmed. That farming was not used more extensively in the US was reported to be due to a less suitable climate, higher prices of coastal land, and more restrictive environmental regulations than in the named countries. The harvesting season extended from May to December in the US.

9 Certain Frozen or Canned Warmwater Shrimp and Prawns from Brazil, China, Ecuador, India, Thailand, and Viet Nam, US International Trade Commission Publication 3748 January 2005. 
There were 125 firms identified as domestic processors of shrimp, and 190 firms reported to be shrimp fisherman. Fresh, frozen, and canned warmwater shrimp were deemed to constitute the domestic industry. That is, the interests of the fisherman and the processors were coincident. There were 36 purchasers of processed warmwater shrimp identified in the US market. Thus there was no monopsony power amongst buyers.

There were 10 product categories identified in the investigation. Subject imports appeared to be differentiated primarily by processing (canned or frozen) and size. Within each category, the good appeared to be approximately homogeneous. ${ }^{10}$

Thirteen processing firms were identified in Brazil, 28 in China, 9 in Ecuador, 83 in India, 37 in Thailand, and 36 in Viet Nam. These constituted from 46.7\% of exports to the US in Brazil to $97.1 \%$ in Viet Nam. Unlike the US industry, the 'vast' majority of subject imports was farmed. The production of aquaculture was deemed to be 'less seasonal', and to have a longer harvest period. While the harvest seasons in the named countries were not coincident, the USITC reported that an imported product category was generally available from a named source at all times.

\section{Final modification for reviews and the final rule}

Because of the publication of the Final Modification, the panel found that Viet Nam had failed to establish that the use of zeroing by the DOC was 'as such' inconsistent with Article 9.3 of the ADA and Article VI:2 of the GATT 1994. The legal standard for an 'as such' determination is 'a measure of general and prospective application'. This is irrespective of practice, as there cannot be a circumstance in which the policy is not implemented. The panel appeared to believe that disuse of zeroing would become the 'general and prospective application'.

In the Final Modification, the DOC refers to retaining 'considerable discretion in selecting an appropriate comparison methodology in reviews'. It also states that 'It is not necessary, appropriate, or desirable' to adopt a 'total prohibition of zeroing', as the Final Modification satisfies 'the WTO settlement reports at issue'. This seems eerily similar to the incrementalism of the compliance by the US in the litany of disputes in which it has been a respondent. Importantly, the Final Modification discloses that the DOC 'will continue to work closely and actively with USTR with

10 I am aware that Chad Bown supplied statistical analysis to the USITC during its material injury investigation which indicated that wild-caught and farmed shrimp are heterogeneous goods, the basis for which is the superior flavor of the wild-caught variety. While this may be true, Jennifer Hillman has suggested that the domestic industry has not pursued the marketing of their product as having superior flavor and texture. Rob Howse has suggested that the actual market distinction can be based upon either of two standards. One is how a rational perfectly informed consumer would view wild-caught versus farmed production. The other is how an actual consumer would view output of the two production methods. Given that domestic producers have not marketed their product as superior, the standard of an actual consumer seems appropriate. 
a view towards clarifying that the $\mathrm{AD}$ Agreement should not be read to require WTO members to provide offsets for non-dumped comparisons'. There is no surrender here.

In response to a request to include regulation of targeted dumping in the Final Modification, the DOC dismissed it as being 'unrelated'. 11 This view was reiterated in the Final Rule issued by the DOC on 22 April 2014. ${ }^{12}$ Under this Rule, targeted dumping, which is defined as exhibiting a pattern of significant differences in export prices among purchasers, regions, or time periods, permits use of zeroing. ${ }^{13}$ In its justification for this Rule, the DOC refers to the need for 'discretion', the benefits to 'refinement' of its approach through 'experience', and the necessity of 'improving its ability to identify and address masked dumping'.

This is worrisome, as Ahn and Messerlin (2014) have noted that the DOC recently has utilized targeted dumping in investigations against 'Bottom Mount Combination Refrigerator-Freezers' from Korea ${ }^{14}$ (final determination on 26 March 2012), and against 'Large Residential Washers' from Korea ${ }^{15}$ (final determination on 26 December 2012). Thus I concur with Ahn and Messerlin (2014) that the definition of targeted dumping lacks discipline, and add that so does 'necessary', 'appropriate', and 'desirable'.

That the panel did agree with Viet Nam that the use of zeroing by the DOC was 'as applied' inconsistent with Article 9.3 of the ADA, and Article VI:2 of the GATT 1994 is of limited consolation. While disagreeing with the 'as such' allegation may not be of operational significance in the context of this dispute, it is of substantial significance with regard to the deterrence of future use of this method of computing $\mathrm{AD}$ margins. Thus the panel left the DOC with too much room to breathe.

\section{What can economics contribute?}

Although there is no statutory requirement in the ADA to determine the reason(s) a firm may have engaged in third degree price discrimination ${ }^{16}$ or may have charged a price below that of unit costs, it is instructive to consider this in the context of the reasonableness of the DOC's AD margins.

Given that the shrimp market is approximately perfectly competitive, third degree price discrimination (Viner, 1923), is not relevant. This requires imperfectly own price elastic demand functions that are reflective of market power, which is arguably absent in this industry. The reciprocal dumping explanation of Brander

1177 Federal Register 8101.

1279 Federal Register 22371.

13 ADA Article 2.4.2.

1477 Federal Register 17413.

1577 Federal Register 75988.

16 Third degree price discrimination refers to charging different prices in segmented markets based upon differences in the own price elasticity of demand in these markets. Segmentation precludes (complete) arbitrage. 
and Krugman (1983) requires international shipping costs and strategic interaction (oligopoly) of firms. It results in an export price net of production costs and international shipping costs that is less than the domestic price net of production costs. This is not relevant here.

Predatory dumping (Bernhofen, 1996; Hartigan, 1994, 1996) requires high entry and re-entry costs. This may provide a foreign firm with an incentive to set a price below the unit costs of domestic competitors so that a monopoly can be established. It requires a firm that can absorb a temporary sacrifice of profits, and is not relevant here either.

In the presence of cyclical demand, excess capacity, and high fixed costs as a percentage of total production costs, a firm may engage in episodic dumping to manage a recession in its (primary) domestic market (Ethier, 1982; Staiger and Wolak, 1992). As the USITC reports, capacity utilization for the period of investigation (January 2001-June 2004) averaged around 90\%. The exports of shrimp constituted about $85 \%$ of total shipments of the foreign producers. Thus this does not appear to provide the motive for dumping.

It is plausible that a firm would introduce 'an experience good' to a new market through a low initial offer (Bagwell and Staiger, 1989). ${ }^{17}$ The low introductory offer would provide inducement to consumers to try a product in lieu of others with established (positive) reputations. It does not seem to work with shrimp.

The explanation of dumping in agricultural and aquacultural markets by Hartigan (2000) seems instructive. This entails a perfectly competitive market in which expected profits over the course of a growing and harvesting period are zero. Actual profits could be positive or negative in the presence of an adverse or beneficial stochastic (probabilistic) shock. Firms contract with itinerant labor at the beginning of the planting season, so that all inputs essentially are fixed for the current season. Since variable costs would be very low, it would be rational to sell at a low price. ${ }^{18}$ Production is zero when out of season. Production is also zero in the growing season. ${ }^{19}$ During the harvest season, production gradually increases, reaches a peak, and gradually declines. If profits are expected to be zero over the harvest and demand is constant, a loss would incur at peak harvest due to higher supply relative to demand, thus inducing lower prices.

The average-to-transaction $(\mathrm{A}-\mathrm{T})$ method of calculating $\mathrm{AD}$ margins is particularly destructive in this context. Under this method, a weighted average of the normal value of foreign market prices is compared to individual export prices.

17 An experience good is one for which, above some threshold, quality cannot be ascertained prior to purchase. This would pertain to, say, autos and consumer electronics. Although the explanation certainly would apply to dumping, Bagwell and Staiger (1989) consider an export subsidy.

18 A firm will sell at a loss as long as total revenue is at least as great as total variable costs.

19 This is most pertinent for goods that are not storable. If they can be stored, or harvesting can be delayed for further growth, this characterization is somewhat restrictive. Aquaculture might be more amenable to delayed harvesting than agriculture. 
As prices vary over the course of a harvest, this method inevitably yields dumping, and may produce high margins. This is a distinctive aspect of agricultural and aquacultural markets.

Article 2.2.1 of the ADA stipulates that prices below unit costs should 'provide for the recovery of all costs within a reasonable period of time'. This article defines the 'ordinary course of trade' to be from six to 12 months. Even if the A-T method is eschewed, dumping can be found if a stochastic shock generates ex post losses despite the expectation of zero profits. The recovery of the losses would not be plausible until the harvest of the succeeding year. Article 2.2.1 provides that sales made below the unit cost of production (fixed and variable) plus average selling, general, and administrative expenses (SG\&A) may, under certain circumstances, be considered 'as sales that are not in the ordinary course of trade'.

This holds only if sales had been made 'within an extended period of time' (normally one year, but in no case less than six months), 'in substantial quantities' (if the weighted average of selling prices of the transactions under consideration is below the weighted average of per unit costs, or if the volume of sales at a loss represents at least 20 per cent of the volume of transactions), and 'at prices which do not allow for the recovery of all costs within a reasonable period of time'. Sales made at prices that are below per unit costs at the time of sale, but above the weighted average per unit costs for the period of investigation, shall be taken into account as means for the 'recovery of costs within a reasonable period of time'.

The wording of Article 2.2.1 ADA does not suggest that what is described above is the only case of sales that are not encompassed by the ordinary course of trade. Case law has provided additional examples of sales outside the ordinary course of trade. ${ }^{20}$

Must trade that is unfair be a matter of volition? Article 2.1 of the ADA refers to the introduction 'into the commerce of another country at less than its normal value'. Article 8 of the ADA addresses the matter of price undertakings which permit suspension or termination of an investigation upon receipt of 'satisfactory' assurances from 'any exporter' that export prices have been revised to eliminate injurious effect to the domestic industry. However, Article 8.3 states that undertakings 'need not be accepted', such as when 'the number of actual or potential

20 In US-Hot-Rolled Steel, sales between parties with common ownership were identified by the $\mathrm{AB}$ as a case of sales outside the ordinary course of trade, but the $\mathrm{AB}$ determined that, even where the parties were entirely independent, a transaction might still not be in the ordinary course of trade, citing as example a liquidation sale by an enterprise to an independent buyer, which may not reflect normal commercial principles. The AB further held in the same case that investigative authorities cannot cherry-pick among sales between related parties. That is, they cannot make the facts fit their judgment. A test applied by the US, which excluded sales transactions between related parties that were marginally low priced while including all high priced sales with the exception of those proven to be aberrantly high priced, ran, in the AB's view, afoul Article 2.2.1 AD. I appreciate Petros Mavroidis for providing me with the material pertaining to 'the ordinary course of trade'. 
exporters is too great'. This suggests that the prices of exports that ostensibly are a cause of injury to the domestic industry can be a matter of competitive pressures, and do not have to be intentionally unfair to qualify as dumping. If an exporter cannot commit to an undertaking because of competition, it is arguable that its 'dumping' is a response to that competition. Nonetheless, the seasonality of prices exhibited in an agricultural or aquacultural market should be regarded as normal and unintentional. Unless a harvest is unusually bountiful, resulting in prices that are below the norm, dumping should not have been deemed to have occurred from mere seasonality.

Because of the prevalence of aquaculture in the named exporting countries, and its limited profile in the US, the seasonality of production and attendant decline in prices, to the extent that it existed, was caused more plausibly by US wild-caught production. Although the prices at peak harvest might benefit the domestic processors at the expense of domestic fisherman, higher prices at other phases of the production cycle would be to their detriment. Since fisherman sell to local processors, direct competition is between the US processing industry and those of the named countries. Consistent with Hartigan (2000), the USITC reports that US processors historically have retained frozen supply for sale during the January to April nonfishing season at higher prices. However, the presence of farmed imported shrimp during this period has mitigated the value of their inventories. Nonetheless, the presence of imports, fairly or allegedly unfairly traded, would have this effect.

In accordance with Article 3.1 of the ADA, material injury must arise in the domestic market. ${ }^{21}$ That is, it must be incurred by domestic producers of subject merchandise. Article 3.2 references a 'significant increase in dumped imports', which can be measured absolutely or relatively. Article 3.5 requires 'a causal relationship between the dumped imports and the injury to the domestic industry'. If the wildcaught harvest of the US industry exhibited greater seasonality than imported production, and this was the source of the decline in domestic prices over which (perfectly competitive) firms have no discretion, it is arguable that a basis of Viet Nam's complaint should have included an Article 3 violation by the US.

\section{Is market structure an available fact?}

The US conducts AD investigations in accordance with Title VII of the Tariff Act of 1930. This act permits the characterization of economies as market or NMEs by US investigative authorities. It is not part of GATT VI or the ADA. It is US practice.

The prices in NMEs are deemed to be unreflective of scarcity, and, hence, fair value. The DOC's investigators are directed to utilize cost and price data from third countries in this instance. The DOC begins with a rebuttable proposition

21 I am grateful to Jennifer Hillman for suggesting that I consider consistency with Article 3. 
that all firms in an NME will receive the same economy-wide rate (EWR). Firms may qualify for a separate rate (SR) if they can establish to the satisfaction of the DOC that they are sufficiently independent of the government in exporting.

This matter arose in US-Shrimp I (Viet Nam), and has been detailed and addressed compellingly by Broude and Moore (2013) with regard to sampling. However, given my introduction of market structure to the discussion, I have a few additional points to include.

The panel asserted that Viet Nam objected to the rebuttable proposition that in an NME all companies belong to a single entity. In this instance, the presumption must be disproven to the satisfaction of the DOC. Viet Nam also contested the manner by which the AD margins were computed, particularly the use of facts available (FA). The panel concurred with Viet Nam that the rebuttable proposition could be challenged 'as applied'. However, it did not agree that the existence of a DOC practice for the calculation of AD margins for NMEs was established that was subject to an 'as such' challenge.

The panel did conclude that the NME-wide entity rate practice could be challenged 'as such' for inconsistency, specifically with regard to Articles 6.10 and 9.2 of the ADA as a matter of general and prospective application. In making this determination, the panel refers to the presumption of a single NME-wide entity. Would this conclusion have been reached in the absence of the presumption? That is, on the basis of the use of FA alone? Plausibly not. There has to be some method of calculating margins in instances of non-cooperation by named firms and/or the submission of inadequate data. Use of such a method is sanctioned by Article 6.8 of the ADA. However, the presumption is not. This method or methods may not have supported a conclusion that all exporters warranted the same AD margin in the absence of the rebuttable presumption.

So is market structure an available fact? Well no, not really. However, I contend that it may be discernible from the facts of the case, and, if so, should be utilized in assessment of the reasonableness of actions by an investigative authority. For example, the investigation will disclose the number of firms producing the named product, the existence of brands and warranties, and the extent of homogeneity of the subject good. The investigative reports of the USITC, for example, include results of a survey of purchasers of the subject import with regard to the importance of such matters as price, quality, interchangeability, safety, and availability. These are indicators of market structure.

Consider the EWR of $25.6 \%$. This was established in the original investigation and has persisted through six administrative reviews. Given that the market is approximately perfectly competitive, it has to be prohibitive. It is unconceivable that the firms saddled with this impediment could compete in the US market. Indeed, even the $4.57 \%$ weighted average $\mathrm{AD}$ margin for mandatory respondents in the original investigation and the first three administrative reviews, and the $3.92 \%$ margin of the fourth administrative review are plausibly prohibitive in an approximately perfectly competitive market; that is, where goods are approximately 
homogeneous. While these separate rates (SR) may or may not be prohibitive, the EWR certainly is. This underscores the importance of the 'individual margin' referenced in Article 6.10, subject to the 'impracticable' constraint. The reference to 'appropriate amounts' in Article 9.2 is delimiting of the discretion of the DOC. It evidently is not a sufficient delimiter, as investigative authorities retain substantial discretion.

I concur with the panel's finding of 'as such' inconsistency with Articles 6.10 and 9.2 in the assignment of a single rate to all exporters of an NME under the presumption that all companies are members of an NME-wide entity. Moreover, I have provided additional justification for an 'as applied' determination of inconsistency. In this complaint, and in possible future complaints involving a large number of exporters of a reasonably homogeneous good, I recommend that an 'as applied' determination take market structure into account. It may, as a matter of policy, be an important distinction between agricultural (including aquacultural) and industrial production. ${ }^{22}$ It is important, however, to be mindful of the extraordinary discretion that the ADA grants investigative authorities.

Of course, as market structure is contextual, this does not inform 'as such' judgments. As the panel asserted that its conclusions with regard to 'as such' inconsistency with Articles 6.10 and 9.2 'are applicable mutatis mutandis' to a consideration of an 'as applied' allegation of inconsistency, one might wonder why I address this determination. My concern is prospective. Suppose that the US withdrew its presumption, or that all of the sources of its exports became market economies, as Viet Nam is doing. There may be future complaints for which an 'as applied' determination is relevant but an 'as such' verdict is not thus my discussion.

Is there a basis within the ADA for asserting that a panel could determine inconsistency of an investigation or review for not assessing the influence of market structure upon pricing and its effects? It does not state so explicitly, but the inference is supportable by its text. Article 2.2 refers to the 'ordinary course of trade'. It is plausible that the 'ordinary course of trade' cannot be ascertained without consideration of market structure. Article 3.4 references 'all relevant economic factors and indices having a bearing upon the state of the industry'. This should include market structure. Article 3.5 mentions 'competition between domestic and foreign producers'. This occurs in the context of a market structure. ${ }^{23}$

The panels for US-Shrimp I (Viet Nam) and US-Shrimp II (Viet Nam) disagreed regarding interpretations of Article 6.8 of the ADA. This pertains to the use of FA when 'necessary information' is not provided 'within a reasonable period' or the

22 The DOC has been more tolerant of sales at a loss in the domestic market of the exporting country in the calculation of normal value for agricultural goods than it has been for industrial goods. This entails the possibility of permitting a higher percentage of sales at a loss, dependent upon perishability and the extent of control that a grower exercises over the timing of harvest (Hartigan, 2000).

23 Recall my discussion of 'ordinary course of trade' in Section 3. 
investigation is 'significantly' impeded by 'any interested party'. The panel for this dispute concluded that because the DOC applied the NME-wide rate computed in the original investigation to that entity in all six subsequent administrative reviews, it did not make any determination in reviews 4,5 , and 6 , which were at issue in USShrimp II (Viet Nam). That is, FA were not invoked. The panel for US-Shrimp I (Viet Nam) concluded that 'to fail to treat this rate as a facts available rate would elevate form over substance, and ignore the true factual circumstances surrounding the assignment of the rate' for the earlier administrative reviews. I concur with the panel for US-Shrimp I (Viet Nam) and disagree with the panel for USShrimp II (Viet Nam). Deciding to utilize a rate from a preceding investigation is, in fact, a determination. What's more, it is more consistent with an objective of the promotion of trade and stare decisis, ${ }^{24}$ and leaves the beast with room to breathe.

\section{Is this an $A D$ case?}

Although it would have been inappropriate for the panel to have considered whether or not an $\mathrm{AD}$ action was the proper venue for redress of the US shrimp industry's viability, it is instructive to speculate about the matter. However, the domain of the panel's analysis is the specific issues alleged by the complainant.

The US shrimp industry, at its discretion, could have filed a petition under Section 201 of the Tariff Act of 1974 instead of Section 731 of the Tariff Act of 1930. That is, it could have filed a safeguards (SG) petition rather than an AD complaint. The lesser injury standard (material vs. serious), ${ }^{25}$ the involvement of a sympathetic DOC, the absence of a provision for an allegation of nullification and impairment of expected benefits (compensation or retaliation), and the absence of a presidential decision may have been good reasons to file an $\mathrm{AD}$ petition. ${ }^{26}$

Consider, however, the purpose of SG. It is, plausibly, either of two objectives. One is to facilitate orderly exit from the production of subject merchandise. This would include reducing employment by attrition through extending the cessation of production over a longer period of time. The other is to facilitate restructuring. This would include plant closure, bankruptcy, and investment in new equipment (Bown, 2002; Sykes, 2006; Hartigan, 2015).

Recall the discussion of the domestic industry in Section 2 above. At the time of the original investigation, US shrimp were $95 \%$ wild-caught, and the 'vast majority' of subject imports were characterized as produced through aquaculture. Farming appeared to modulate seasonality and provide more consistent size and quality of harvest. ${ }^{27}$ That the US did not implement aquaculture to a greater extent was

24 I recognize that, while desirable in the absence of errors, precedent is not binding.

25 See the texts of the ASG and ADA at www.wto.org.

26 See Hartigan and Vandenbussche (2013).

27 USITC, publication 3748. 
reputedly due to coastal land prices, climate, and environmental regulations. This appears to epitomize the need for orderly exit. Thus SG measures seemingly would have been more appropriate than $\mathrm{AD}$ duties. The facts did not portend a future globally competitive US shrimp industry.

However, this is changing, and in a way that underscores the appropriateness of SG as the petition that should have been filed. On 2 July 2014, the New York Times published an article about the emergence of the indoor shrimp aquacultural industry in the US. ${ }^{28}$ This evolving and innovative industry uses 'fiberglass tanks fitted with advanced recirculation, filtration, and temperature control systems'. It relies upon tanks of sea water from the Atlantic Ocean. This water is 'filtered and reused from harvest to harvest'. It does not utilize antibiotics, hormones, or pesticides. In the five years leading up to the article, the number of such farms has increased from two to at least 22 in the US. This suggests that the advantages in the technology of the US may overcome the disadvantages in labor costs, land prices, and regulatory requirements in sustaining a viable domestic industry. It would appear that there would be some churning, however, as the emerging businesses may differ in ownership and location from those that are contracting. This is a natural evolution of a market that arguably does not have much to do with dumping, but its adjustment costs may be mitigated by SG.

Given the magnitude of the AD margins for an NME-wide entity in the context of an approximately perfectly competitive market, I infer that an AD margin of 25.6 is indicative of sales at a loss or cost of dumping. That is, unless the NME entity was being subsidized. In such an instance, a petition under the ASCVM agreement would have been more appropriate, and these margins more defensible. However, a subsidy in an NME may not be countervailable, as there isn't any market to distort. ${ }^{29}$ As Feldman and Burke (2013) discuss, the US began to initiate $\mathrm{AD}$ and countervailing duty investigations simultaneously against China in 2006, generating legal controversy at the US Court of International Trade and the US Court of Appeals for the Federal Circuit. Ramanujan and Sampath (2015) critique panel and $\mathrm{AB}$ reports over this pairing of measures. Thus a SG petition arguably was more appropriate than one alleging subsidization. ${ }^{30}$

In discussing the advantages of the new techniques of aquaculture, I note the absence of hormones, antibiotics, and pesticides. This continues with a discussion of food safety and the SPS Agreement. I note, in this regard, that the USITC report for the original investigation refers to the use of antibiotics in shrimp farming. That report also mentions that less than $2 \%$ of imports are inspected by the Federal Drug Administration (FDA), while domestic production is subject to 'multiple US government regulations'. This includes state boards of health and the

28 www.nytimes.com/2014/july-2.

2963 Federal Register 65348, 65360.

30 Beshkar and Chilton (2016) is also relevant. 
Hazardous Analysis Critical Control Points (HACCP). The USITC report contains allegations of US processors that the regulations are 'effectively different' between US and imported production. In addition to the investigation, there are other reports of concern in the EU, Japan, and the US over the use of antibiotics, disinfectants, and pesticides in shrimp farming in developing countries. ${ }^{31}$

This would appear to be a matter for Article XX(b) of the GATT and the SPS agreement. Article 1 establishes the domain of the Agreement as SPS measures that 'may, directly or indirectly, affect international trade'. Article 2(1) of the SPS refers to a right to protect 'human, animal, or plant life or health'. Article 2 (2) states that such protection should only be 'to the extent necessary'. The chapeau of the SPS Agreement, Articles 5, 9, and 10, and Annexes A, B, and C refer to 'appropriate' levels of protection. Implementing increased inspection of imported shrimp plausibly could protect the domestic industry by introducing or raising compliance costs of foreign producers, thereby leading to higher domestic prices through reduced foreign supply. While AD duties impose a pure surplus loss upon domestic consumers, an SPS measure would provide them a benefit for paying higher prices. This arguably would be a safer product and/or lead to more confidence in the product's safety. The negative implication is that invocation of SPS in such an instance would be an example of what Bhagwati (1988) has termed the 'law of constant protectionism'. That is, curtailment of one instrument for protecting a domestic industry induces the emergence of an alternative measure.

\section{Conclusion}

US-Shrimp II (Viet Nam) should not be viewed as just another zeroing case without anything to add to the critiques of previous panels. There were two pronouncements by the DOC for which Shrimp II was the first relevant dispute. The initial one was the Final Modification for Reviews in February 2012 in which the DOC appeared to concede that its campaign to legitimize the use of zeroing in the calculation of margins had failed. The Final Modification was released two days prior to the request for consultations by Viet Nam. ${ }^{32}$ However, a mere two years later, in April 2014, the DOC was back. This time it released its Final Rule for the calculation of AD margins in instances of targeted dumping. It asserted substantial discretion in making such computations. Since targeted dumping was claimed as an exception in the renouncement of zeroing in the Final Modification, the DOC appears to be reverting to its discredited ways. Thus the

31 See, for example, www.foodandwaterwatch.org/reports/suspicious-shrimp.

32 The sixth administrative review, a subject of contention in this dispute, was in process at the time that the Final Modification was announced and the nearly simultaneous request for consultations occurred. It is arguable that these consultations could have mitigated the disagreement if the DOC was willing to implement the Final Modification in the ongoing sixth review. 
panel, in my view, not only missed an opportunity to continue to apply pressure on the DOC, it also appeared to be endorsing its interpretation.

I also discuss dumping in the context of an approximately perfectly competitive market which exhibits seasonality in production. I suggest that it may not have been appropriate to have characterized the pricing behavior in the US frozen shrimp market as dumping. Indeed, it is arguable that Viet Nam should have included an allegation of an Article 3 violation of the ADA in its complaint.

This continues with a consideration of alternative policies to address the difficulties of the shrimp industry in the US. A petition under the ASCVM is deemed to be of questionable legality. However, an SG petition fits the facts and recent developments in the industry rather well. There also appears, as I discuss, a basis for an SPS measure. Unlike the 'new protectionism' of administered protection (AD, SG, subsidies), an SPS measure has the potential of providing a benefit to domestic consumers in the form of a safer product to mitigate the effects of higher prices. An AD or SG duty imposes a pure welfare loss upon consumers in the importing country. Thus what I term the new new protectionism of SPS may be contended as the preferred way to proceed.

\section{References}

Ahn, D. and P. Messerlin (2014), 'United States-Anti-Dumping Measures on Certain Shrimp and Diamond Sawblades from China: Never Ending Zeroing in the WTO?', World Trade Review, 13(2): 267-279.

Bagwell, K. and R. W. Staiger (1989), 'The Role of Export Subsidies When Product Quality Is Unknown', Journal of International Economics, 27(1-2): 69-89.

Bernhofen, D. M. (1996), 'Vertical Integration and International Predation', Review of International Economics, 4(1): 90-98.

Beshkar, M. and A. S. Chilton (2016), 'United States - Countervailing and Anti-Dumping Measures on Certain Products from China (DS449)', World Trade Review, 15 (this issue).

Bhagwati, J. (1988), Protectionism, Cambridge, MA: MIT Press.

Bown, C. P. (2002), 'Why Are Safeguards under the WTO So Unpopular?', World Trade Review, 1(1): 47-62.

Bown, C. P. and T. J. Prusa, (2011), 'US Antidumping: Much Ado about Zeroing', in W. J. Martin and A. Mattoo (eds.), Unfinished Business? The WTO's Doha Agenda, London, UK: CEPR and World Bank, pp. 355-392.

- and A. O. Sykes (2008), 'The Zeroing Issue: A Critical Analysis of Softwood V', World Trade Review, 7(1): 121-142.

Brander, J. and P. Krugman (1983), 'A “Reciprocal Dumping” Model of International Trade', Journal of International Economics, 15(3): 313-321.

Broude, T. and M. Moore (2013), 'US - Anti-Dumping Measures on Certain Shrimp from Viet Nam: A Stir-Fry of Seafood, Statistics and Lacunae', World Trade Review, 12(2): 433-462.

Ethier, W. J. (1982), 'Dumping', Journal of Political Economy, 90(3): 487-506.

Feldman, E. J. and J. J. Burke (2013), 'Testing the Limits of Trade Law Rationality: The GPX Case and Subsidies in Non-market Economies', American University Law Review, 62(4): 787-825.

Hartigan, J. C. (1994), 'Dumping and Signaling', Journal of Economic Behavior and Organization, 23(1): 69-81.

— (1996), 'Predatory Dumping', Canadian Journal of Economics, 29(1): 228-239.

(2000), Is the GATT/WTO Biased Against Agricultural Products in Unfair International Trade Investigations?', Review of International Economics, 8(4): 634-646. 
_ (2015), 'Did the Agreement on Safeguards Nullify Their Use?', Global Economy Journal, 15(1): 155172.

- and H. Vandenbussche (2013), 'Disfavored Nations: Anti-Dumping at the WTO', Review of Development Economics, 17(1): 105-116.

Hoekman, B. and J. Wauters (2011), 'US Compliance with WTO Rulings in Anti-Dumping', World Trade Review, 10(1): 5-43.

Prusa, T. J. and L. Roubini (2013), 'United States-Use of Zeroing in Anti-Dumping Measures Involving Products from Korea: It's Déjà Vu All over Again', World Trade Review, 12(2): 409-425.

- and E. Vermulst (2011), 'United States-Continued Existence and Application of Zeroing Methodology: The End of Zeroing?, World Trade Review, 10(1): 45-61.

Ramanujan, A. and S. Sampath (2015), 'Double Counting: Is There Light at the End of the Tunnel?', Journal of World Trade, 49(2): 223-251.

Saggi, K. and M. Wu (2013), 'Yet Another Nail in the Coffin of Zeroing: United States-Anti-Dumping Administrative Reviews and Other Measures Related to Imports of Certain Orange Juice from Brazil', World Trade Review, 12(2): 377-408.

Staiger, R. W. and F. A. Wolak (1992), 'The Effect of Domestic Antidumping Law in the Presence of Foreign Monopoly', Journal of International Economics, 32(3-4): 265-287.

Sykes, A. O. (2006), The WTO Agreement on Safeguards: A Commentary, Oxford: Oxford University Press.

Viner, J. (1923), Dumping: A Problem in International Trade, Chicago: University of Chicago Press. 